\title{
Physicochemical Modifications in Geomaterials and Their Leachates Extracted from Acidic Attack
}

\author{
S.T. Ferrazzo, R.S. Tímbola, L. Bragagnolo, E. Prestes, E.P. Korf, P.D.M. Prietto, G.D.L.P. Vargas
}

\begin{abstract}
Exposure of geomaterials to acid leachates may cause chemical species desorption, mineral dissolution, and metal leaching. This study seeks to understand the changes in the physicochemical composition of liquid extracts resulting from the exposure of four different geomaterials (uniform fine sand, basalt residual soil, kaolin, and bentonite) to a blank solution (distilled water) and sulfuric acid solutions at the concentrations of 0.01 , and $1.00 \mathrm{~mol} / \mathrm{L}$. It was also investigated the relationship between alterations in both chemical and mineralogical constitutions of geomaterials. The elemental composition of the geomaterials was determined by X-ray fluorescence. In the liquid extracts, $\mathrm{Na}, \mathrm{Mg}, \mathrm{Al}, \mathrm{K}, \mathrm{Ca}, \mathrm{Fe}$, and Mn concentrations were obtained by inductively coupled plasma atomic emission spectrometry, as well as pH and electrical conductivity were evaluated. $\mathrm{pH}$ and electrical conductivity data showed that bentonite had buffering capacity until $0.01 \mathrm{~mol} / \mathrm{L}$ concentration and higher ion dissolution with increasing acid concentration. Acidic attack by the $1.00 \mathrm{~mol} / \mathrm{L}$ solution resulted in the solubilization of the constituent metals, corresponding to reductions in elemental composition and alterations in geomaterials mineralogy.
\end{abstract}

Keywords: clayey, metal solubilization, mineralogy, silty and sandy soils, sulfuric acid.

\section{Introduction}

Anthropogenic processes may cause modification in soil behavior due to contamination by acidic solutions, which, under extreme conditions $(\mathrm{pH}<1)$, result in significant volumetric variations and structural changes in soils (Chavali et al., 2018). Considered chemically aggressive, acidic leachates from industrial and mining solid wastes constitute a considerable source of environmental impact, causing changes in soil structure, as increased hydraulic conductivity and reduced reactive power. Acidic $\mathrm{pH}$ solutions increase the mobility of dissolved contaminants, which have the main destination at soil and water resources (Agbenyeku et al., 2016; Candeias et al., 2014; GonzálezFernández et al., 2018; Grande et al., 2018; Hueckel et al., 1997; Knop et al., 2008; Pecorini et al., 2017).

Usually, geomaterials are used in waste containment liner systems, as mixtures of clayey soils and cement, with or without bentonite added, to improve hydraulic and reactive properties of contention barrier (Ghadr \& Assadi-Langroudi, 2018; Gueddouda et al., 2016; Hassanlourad et al., 2016; Mao et al., 2018; Miguel et al., 2017; Morandini \& Leite, 2015; Verástegui-Flores \& Di Emidio, 2014; Wang et al., 2018, 2016). It has been recognized that high plasticity clayey soils are likely to lose structure when in contact with leachates containing multispecies contaminants, thus reducing their impermeability potential (Amadi, 2011). Therefore, for the efficient performance of liner systems, properties of the geomaterials must not be compromised over time by the exposure to acidic leachates (such as mining drainage). Therefore, the study of the interaction between clay soil constituents and high acidity solutions, focusing on changes in chemical and mineralogical composition, is fundamental for the correct management, as well as the treatment of contaminated soils (Agbenyeku et al., 2016).

Several studies in the literature reporting the effects of exposure of geotechnical materials to chemically aggressive solutions (Agbenyeku et al., 2016; Chavali et al., 2017, 2018; Hamdi \& Srasra, 2013; Li et al., 2013; Liu et al., 2015; Miguel et al., 2017; Sucha et al., 2002; Verástegui-Flores \& Di Emidio, 2014), indicate, in general, that contact with acidic waters causes soil $\mathrm{pH}$ reduction, metal dissolution, chemical species desorption (Agbenyeku et al., 2016; Miguel et al., 2017), and cation exchange reactions

Suéllen Tonatto Ferrazzo, M.Sc., Programa de Pós-Graduação em Ciência e Tecnologia Ambiental, Universidade Federal da Fronteira Sul, Erechim, RS, Brazil. e-mail suellenferrazzo@hotmail.com.

Rafael de Souza Tímbola, D.Sc. Student, Programa de Pós-Graduação em Engenharia Civil e Ambiental, Universidade de Passo Fundo, Passo Fundo, RS, Brazil. e-mail rafaeltimbola@hotmail.com

Lucimara Bragagnolo, M.Sc. Student, Programa de Pós-Graduação em Ciência e Tecnologia Ambiental, Universidade Federal da Fronteira Sul, Erechim, RS, Brazil. e-mail lucimarabragagnolo@hotmail.com.

Elvis Prestes, Student, Curso de Engenharia Ambiental e Sanitária, Universidade Federal da Fronteira Sul, Erechim, RS, Brasil. e-mail prestes.elvis@gmail.com.

Eduardo Pavan Korf, D.Sc., Associate Professor, Programa de Pós-Graduação em Ciência e Tecnologia Ambiental, Universidade Federal da Fronteira Sul, Erechim, RS, Brazil. e-mail eduardo.korf@uffs.edu.br.

Pedro Domingos Marques Prietto, D.Sc., Assistent Professor, Programa de Pós-Graduação em Engenharia Civil e Ambiental, Universidade de Passo Fundo, Passo Fundo, RS, Brazil. e-mail pdmp@upf.br.

Gean Delise Leal Pasquali Vargas, D.Sc. Associate Professor, Programa de Pós-Graduação em Ciência e Tecnologia Ambiental, Universidade Federal da Fronteira Sul, Erechim, RS, Brazil. e-mail geandelise@uffs.edu.br.

Submitted on November 7, 2019; Final Acceptance on April 17, 2020; Discussion open until September 30, 2020.

DOI: $10.28927 /$ SR.432279 
with partial mineral dissolution (Chavali et al., 2018), in addition to changes in hydraulic conductivity in clayey soils (Hamdi \& Srasra, 2013; Li et al., 2013; Liu et al., 2015) and modifications in their mechanical properties (Hassanlourad et al., 2016). However, Chavali et al. (2018) highlight that most of these studies evaluate soil contamination by inorganic acidic solutions with $\mathrm{pH}$ under natural conditions $(3<\mathrm{pH}<6)$. However, this $\mathrm{pH}$ range covers natural $\mathrm{pH}$ values in some Brazilian soils, such as Cerrado soils (pH 3.75-4.85) (Leite et al., 2006; Leite et al., 2018) and basalt residual soil (pH 5.5) (Korf et al., 2020).

Thus, further studies are needed to evaluate changes in soils in contact with more aggressive acidic solutions at $\mathrm{pH}$ below 1, such as those from mine drainage storage ponds, where water evaporation causes the increase in hydrogen ion concentration (Liu et al., 2013). These wastewaters contain sulfuric acid molecules generated by the oxidation of sulfide minerals in the presence of oxygen and water. A decrease in $\mathrm{pH}$ increases the solubility of soil and rock constituents (Knop et al., 2008). Also, it may occur acidic contamination of soils not only by sulfuric acid from spills or leaks (Chavali et al., 2018) but also by acid mine drainage (AMD) from mining in coal plants (Liu et al., 2013) and mining of metallic sulfide ores (Blowes et al., 2014; Luo et al., 2020).

Therefore, this study seeks to shed light on the alterations in geotechnical materials as they are exposed to different concentrations of sulfuric acid with $\mathrm{pH}$ lower than 1 , by investigating the changes in the physicochemical composition of the liquid extract resulting from the exposure of four geomaterials to sulfuric acid solutions, as well as the changes in the elemental composition and its relationship with the mineralogy of each geomaterial tested. A better understanding of the alterations in geomaterials as a result of the acid attack may be helpful in designing and modeling of compacted barriers, as well as predicting the response of foundation soils.

\section{Methodology}

\subsection{Materials}

In this study, the following geomaterials were used: Osorio Fine Sand (OFS), Basalt Residual Soil (BRS), Kaolin (KAO), and sodium Bentonite (BEN). The sand was collected in a natural deposit in the municipality of Osorio, in the Rio Grande do Sul state, in southern Brazil, and it is considered uniform fine sand (ABNT, 1995; ASTM, 1993). The Basalt residual soil was collected at the Experimental Geotechnical Field of the Technology Center (CETEC) of the University of Passo Fundo (UPF), in the Rio Grande do Sul state, Brazil. It is characterized as a Humic Dystrophic Red Latosol (Streck et al., 2008), with high clay content, classified as low plasticity clay (ASTM, 1993). The Kaolin was purchased from a mineral products supplier located in the municipality of Pântano Grande, in the state of Rio
Grande do Sul, Brazil. This material is commercially known as "pink kaolin" and is classified as a low plasticity inorganic silt (ASTM, 1993). Sodium bentonite of white color was obtained from a supplier located in the municipality of Soledade, in the state of Paraíba, in northeast Brazil, and is classified as a high plasticity inorganic clay (ASTM, 1993). Sulfuric acid used in the experiments was grade P.A., Merck brand with purity $95-97 \%$ and density $1.84 \mathrm{~g} . \mathrm{cm}^{-3}$.

\subsection{Methods}

The preparation of the geomaterials testing samples followed the standard NBR 6457 (ABNT, 2016). The acidic attack on the geomaterials was simulated by a batch testing adapted from ASTM D4646 - 03 (ASTM, 2008). In these tests, the following variables were considered: sulfuric acid concentration at $0.00 \mathrm{~mol} / \mathrm{L}$ ( $\mathrm{pH}$ of distilled water equal to $7 \pm 2$ ), $0.01 \mathrm{~mol} / \mathrm{L}(\mathrm{pH} 2)$ and $1.00 \mathrm{~mol} / \mathrm{L}(\mathrm{pH} 0)$, and four geomaterials (OFS, BRS, KAO and BEN), resulting in 12 experimental treatments. The batch tests procedures were as follow:

a) Insertion of samples of each material into a $2000 \mathrm{~mL}$ Erlenmeyer flask at a soil-solution ratio of 1:20;

b) Horizontal continuous shaking at 215 rotations per minute for $24 \mathrm{~h}$ at $22 \pm 5^{\circ} \mathrm{C}$;

c) Decantation and centrifugation of samples to separate solid and liquid phases. The supernatant centrifugation process was performed in a centrifuge under $3000 \mathrm{rpm}$ for $10 \mathrm{~min}$ (USEPA, 1996). Subsequently, the liquid extract was filtered through a $0.45 \mu \mathrm{m}$ nitrocellulose membrane;

d) Drying of the resulting solid material, in porcelain capsules, in an oven at a temperature of 40 to $50{ }^{\circ} \mathrm{C}$, until constancy of mass. After, each sample was macerated in porcelain crucibles until a powdery material was obtained and placed in properly sealed and identified plastic bags.

Liquid extracts were physical-chemically characterized through the determination of $\mathrm{pH}$ and electrical conductivity. $\mathrm{pH}$ was determined by $\mathrm{pH}$ meter, model HI 2221 Hanna brand, glass body $\mathrm{Ag} / \mathrm{AgCl}$ electrode with ceramic junction, diameter $9.5 \mathrm{~mm}, \mathrm{pH}$ range 0 to 13 and temperature $20-40{ }^{\circ} \mathrm{C}$. Electrical conductivity was determined by microprocessor conductivity meter, model DM-32 Digimed brand with conductivity cell/sensor DMC-010M (ran-

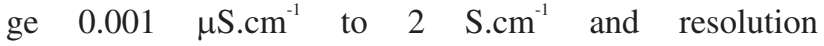
0.001/0.01/0.1/1). Also, $\mathrm{Na}, \mathrm{Mg}, \mathrm{Al}, \mathrm{K}, \mathrm{Ca}, \mathrm{Fe}$, and $\mathrm{Mn}$ concentrations were determined for the experimental treatments corresponding to the extremes of the acidic range concentration $(0.00 \mathrm{~mol} / \mathrm{L}$ and $1.00 \mathrm{~mol} / \mathrm{L})$ by inductively coupled plasma atomic emission spectrometry (Shimadzubranded ICP-AES). The pattern solution used to running at ICP-AES was multi element standard XXI for ICP Certipur Merck brand (30 elements in diluted nitric acid- $\mathrm{HNO}_{3}$ ). 
The chemical compositions of the geomaterials, before and after the acidic attack, were determined by X-ray fluorescence spectrometry (XRF), in a pressed sample, with the STD-1 calibration, allowing for the non-standard analysis of the chemical elements comprised between fluoride and uranium in a Bruker S8 Tiger spectrometer.

The mineralogical constitutions were determined by $\mathrm{X}$-ray diffraction (XRD), by the powder method, in a Bruker X-ray diffractometer, model D8 Endeavor, with a position-sensitive detector. The identification of the crystalline phases was obtained by comparing the sample diffractogram with the International Center for Diffraction Data (ICDD) PDF2 database using the X'Pert High Score software.

\section{Results and Discussion}

Figure 1 shows the $\mathrm{pH}$ and electrical conductivity results of the liquid extracts for the four tested geomaterials. The $\mathrm{pH}$ results of the OFS, BRS, and KAO remained close to the initial $\mathrm{pH}$ of the acidic solutions to which they were exposed. BEN presented $\mathrm{pH}$ above neutrality, especially the sample submitted to the $0.01 \mathrm{~mol} / \mathrm{L}$ solution ( $\mathrm{pH} 2$ ), due to the acid buffering power associated with the high cation exchange capacity of this soil (Nessa et al., 2007). BEN also presented the highest $\mathrm{pH}$ value (0.41) amongst the geomaterials tested at $1.00 \mathrm{~mol} / \mathrm{L}$ concentration $(\mathrm{pH} 0)$. Similar results were observed by Liu et al. (2013), who
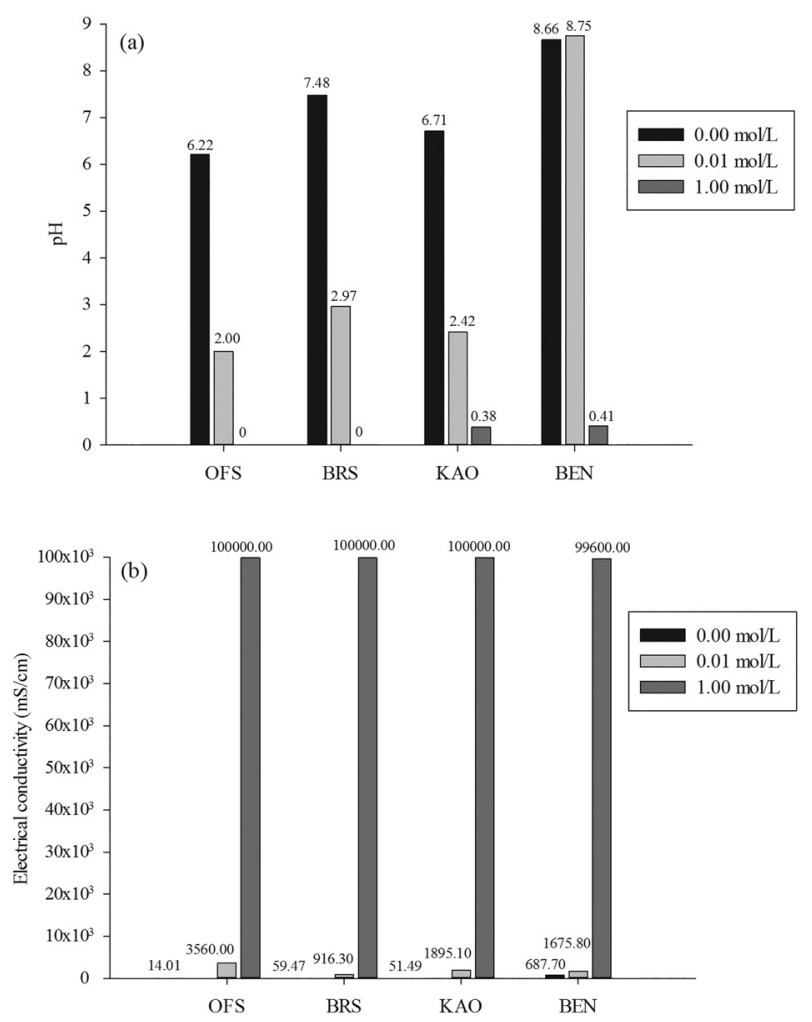

Figure 1 - $\mathrm{pH}$ (a) and electrical conductivity (b) of the liquid extract of the geomaterials tested. evaluated that acidic leachate from three sodium bentonites had $\mathrm{pH} \sim 2$ at lower concentrations $(0.015 \mathrm{~mol} / \mathrm{L}$ to $0.25 \mathrm{~mol} / \mathrm{L})$, and $\mathrm{pH} \sim 0$ at higher concentrations $(0.5 \mathrm{~mol} / \mathrm{L}$ and $1 \mathrm{~mol} / \mathrm{L}$ ).

The results indicate that bentonite has a higher acid neutralization capacity at $0.01 \mathrm{~mol} / \mathrm{L}$ solution $(\mathrm{pH} 2)$. This condition may contribute to the attenuation of contaminants from acidic leachate. According to Yong et al. (1990), smectite soil (e.g. bentonite) shows significant resistance to $\mathrm{pH}$ changes due to its high cation-exchange capacity (CEC). The $\mathrm{H}^{+}$adsorption from smectite-contamination leachate occurs mainly by cation exchange, and when exchange sites are unavailable, the $\mathrm{pH}$ decreases rapidly. On the other hand, kaolinite soil does not show considerable resistance to $\mathrm{pH}$ changes (Yong et al., 1990), which was observed in BRS and KAO samples.

In general, all geomaterials presented a positive correlation between electrical conductivity and concentration of sulfuric acid, which indicates a higher concentration of dissolved ions in the liquid extracts at $1.00 \mathrm{~mol} / \mathrm{L}$. The results of metals concentration by ICP-AES (Table 1) and the XRF (Table 2) indicate the solubilization of the chemical constituents of geomaterials. For the OFS, the significant electrical conductivity measured in the liquid extract of the sample at $1.00 \mathrm{~mol} / \mathrm{L}$, is probably due to the presence of hydrogen ions $\left(\mathrm{H}^{+}\right)$in the solution, which did not bind to the active sites of the soil minerals, since quartz has low reactivity to sulfuric acid.

Table 1 shows the metals concentrations in the liquid extract resulting from the geomaterials tested at the extreme values of the concentration range $(0.00 \mathrm{~mol} / \mathrm{L}$ and $1.00 \mathrm{~mol} / \mathrm{L}$ ). These results are consistent with the chemical constitution of the samples (Table 2), demonstrating that exposure to the $1.00 \mathrm{~mol} / \mathrm{L}$ solution of sulfuric acid caused loss by solubilization of the constituent metals of the geomaterials, mostly aluminum $(\mathrm{Al})$, iron $(\mathrm{Fe})$, calcium $(\mathrm{Ca})$, and magnesium $(\mathrm{Mg})$, in addition to sodium $(\mathrm{Na})$ for the bentonite liquid extract. Knop et al. (2008) reported that these metals are commonly mobilized in rocks or soils due to the leaching of sulfuric acid present in acidic mining drainage.

The expressive concentrations of $\mathrm{Fe}$ in the liquid extracts were an expected result since this metal is highly soluble in acidic environments. This feature was observed mainly for the BRS, which has significant Fe content in its natural composition (see Table 2). For the specimen SRB at $1.00 \mathrm{~mol} / \mathrm{L}$, it was observed a $\mathrm{Fe}$ concentration of $458 \mathrm{mg} / \mathrm{L}$, confirming the loss of hematite identified by the XRD analysis (Table 3). According to Sunil et al. (2006), Fe leaching from a lateritic soil reduces the bonds between soil particles, resulting in alterations in their mechanical and physical properties, such as reduced compressive strength and maximum dry density and increased optimal moisture content. Also, a high concentration of aluminum was detected in the liquid extracts, corroborating the idea 
Table 1 - Metal concentration of liquid geomaterials extract (mg/L).

\begin{tabular}{|c|c|c|c|c|c|c|c|}
\hline Specimen & $\mathrm{Na}$ & $\mathrm{Mg}$ & $\mathrm{Al}$ & $\mathrm{K}$ & $\mathrm{Ca}$ & $\mathrm{Fe}$ & $\mathrm{Mn}$ \\
\hline OFS $0.00 \mathrm{~mol} / \mathrm{L}$ & -1 & 0.21 & 2.31 & $-{ }^{1}$ & -1 & 0.85 & -1 \\
\hline OFS $1.00 \mathrm{~mol} / \mathrm{L}$ & -1 & 1.79 & 10.03 & 1.06 & 2.16 & 6.94 & 0.16 \\
\hline BRS $0.00 \mathrm{~mol} / \mathrm{L}$ & -1 & 0.85 & $-{ }^{1}$ & -1 & 1.69 & 0.06 & 0.24 \\
\hline BRS $1.00 \mathrm{~mol} / \mathrm{L}$ & -1 & 4.27 & 418.12 & 1.99 & 8.39 & 458.12 & 3.00 \\
\hline $\mathrm{KAO} 0.00 \mathrm{~mol} / \mathrm{L}$ & -1 & 0.49 & 7.34 & 1.47 & 0.04 & 1.14 & $-{ }^{1}$ \\
\hline $\mathrm{KAO} 1.00 \mathrm{~mol} / \mathrm{L}$ & $-{ }^{1}$ & 12.93 & 205.98 & 8.56 & 14.10 & 9.57 & 1.91 \\
\hline $\mathrm{BEN} 0.00 \mathrm{~mol} / \mathrm{L}$ & 161.98 & 11.27 & 96.32 & 2.64 & 5.27 & 38.00 & 0.05 \\
\hline $\mathrm{BEN} 1.00 \mathrm{~mol} / \mathrm{L}$ & 332.97 & 132.99 & 136.32 & 8.63 & 282.50 & 46.33 & 0.86 \\
\hline
\end{tabular}

${ }^{1}$ : Below detection limit.

Table 2 - Elemental chemical composition of solid extracts of geomaterials ( $\mathrm{mg} / \mathrm{kg}$ ).

\begin{tabular}{lccccccccccccc}
\hline Specimen & $\mathrm{Na}$ & $\mathrm{Mg}$ & $\mathrm{Al}$ & $\mathrm{P}$ & $\mathrm{Si}$ & $\mathrm{S}$ & $\mathrm{K}$ & $\mathrm{Ca}$ & $\mathrm{Ti}$ & $\mathrm{Fe}$ & $\mathrm{Mn}$ & $\mathrm{Zr}$ & $\mathrm{Ba}$ \\
\hline OFS Pure & 900 & 400 & 11600 & - & 435200 & 100 & 7100 & 500 & 900 & 2800 & - & - \\
OFS 0.00 mol/L & 900 & 300 & 9900 & - & 445500 & - & 6000 & 400 & 700 & 2100 & - & - & - \\
OFS $1.00 \mathrm{~mol} / \mathrm{L}$ & - & - & 5800 & - & 401600 & 11300 & 5100 & - & 500 & 2000 & - & - & - \\
BRS Pure & - & 2100 & 128100 & 500 & 216900 & 300 & 3400 & 200 & 9800 & 74800 & 300 & 500 & - \\
BRS 0.00 mol/L & - & 1700 & 109600 & 400 & 232300 & 300 & - & 300 & 9400 & 73400 & 300 & - & - \\
BRS $1.00 \mathrm{~mol} / \mathrm{L}$ & - & 600 & 37500 & - & 94000 & 63700 & - & 200 & 3800 & 27000 & - & 200 & - \\
KAO Pure & - & 900 & 189500 & 100 & 221600 & 300 & 7000 & 800 & 900 & 8200 & 100 & - & 500 \\
KAO 0.00 mol/L & - & 500 & 191600 & - & 216900 & - & 8900 & 900 & 1300 & 11600 & - & - & - \\
KAO 1.00 mol/L & - & 500 & 128600 & - & 143500 & 31800 & 5600 & 700 & 600 & 6200 & - & - & - \\
BEN Pure & 5900 & 5900 & 166200 & 200 & 217400 & 100 & 10300 & 8400 & 2200 & 18300 & 100 & 100 & 400 \\
BEN 0.00 mol/L & 2400 & 5100 & 130200 & - & 247300 & - & 24100 & 17800 & 1600 & 15700 & - & 200 & 600 \\
BEN 1.00 mol/L & 900 & 3200 & 102700 & - & 162200 & 35600 & 7300 & 1600 & 1500 & 12900 & - & 100 & 400 \\
\hline
\end{tabular}

that at very low $\mathrm{pH}$ values (less than 4.5 ), this metal is solubilized in the forms of $\mathrm{Al}^{+3}$ and $\mathrm{AlO}_{2}^{-}$(Miguel et al., 2017).

Spagnoli et al. (2012) reported that, in a solution with $\mathrm{pH}$ close to $3, \mathrm{Al}^{+3}$ dissolution acts as a coagulant agent in kaolinite, increasing shear strength. According to the authors, the occurrence of clay mineral dissolution in acidic environments is a function of protonation reactions of the hydroxide $\left(\mathrm{OH}^{-}\right)$and oxide $\left(\mathrm{O}^{2-}\right)$ termination sites, which weaken the bonds that support the aluminum and, consequently, displace it from the structure to the liquid phase as $\mathrm{Al}^{3+}$. In the study of Bakhshipour et al. (2016), it was found that the reduction of aluminum and iron contents of a residual soil by acidic leaching increased Atterberg limits and optimum moisture content and reduced shear strength and maximum dry density.

For the BEN sample, the acidic attack resulted in an increase of sodium, calcium, and magnesium in the liquid extract. The desorption of these bentonite elements is supported by the results of the XRF analysis (Table 2). This feature was probably due to the bentonite high cation exchange capacity (Asof et al., 2017; Caglar et al., 2013; Koch, 2002). According to Liu et al. (2013), the concentrations of sodium and calcium in leachates of sodium bentonite reflect hydrogen ion exchanges. The authors reported that around $90 \%$ and $50 \%$ of $\mathrm{Na}$ and $\mathrm{Ca}$, respectively, were displaced by $\mathrm{H}^{+}$.

Considering the application of bentonite in waste containment liner systems and degraded areas exposed to acid contaminants, the loss of cations from bentonite, as observed in this study, points out to potential changes in expansion capacity, plasticity, microstructure, and permeability (Bouazza et al., 2006; Egloffstein, 2001; Koch, 2002; Mazzieri et al., 2017; Ruhl \& Daniel, 1997; Shackelford et al., 2000). Chavali et al. (2018) reported that contamination of sodium bentonite by sulfuric acid caused a reduction in the expansion of this clay, where equilibrium expandabilities of $67 \%$ and $50 \%$ were measured at $1 \mathrm{~mol} / \mathrm{L}$ and $4 \mathrm{~mol} / \mathrm{L}$ concentrations, respectively. According to the authors, these changes in bentonite are due to the cation ex- 
change process, in which sodium ions are replaced by hydrogen ions, whose ionic radius $(0.012 \mathrm{~A})$ is smaller than that of sodium (1.02 A), resulting thus in smaller expansion. Liu et al. (2013), for three sodium bentonites, found that the contact with sulfuric acid solutions $(0.015 \mathrm{~mol} / \mathrm{L}$ to $1 \mathrm{~mol} / \mathrm{L}$ ) caused the displacement of cation ions by hydrogen ions, resulting in a reduction of Atterberg limits and expandability index, which might compromise the hydraulic performance of these geomaterials when applied in waterproofing systems.

The elemental characterization presented in Table 2 is consistent with the metal concentrations found in the liquid extracts, for all geomaterials exposed at $1.00 \mathrm{~mol} / \mathrm{L}$, demonstrating expressive reductions of $\mathrm{Fe}, \mathrm{Al}, \mathrm{Mg}, \mathrm{Ca}$, and $\mathrm{Na}$ in sodium bentonite.

Table 3 shows the mineralogical compositions of the geomaterials samples. In line with the results of the FRX (Table 2) and ICP-AES (Table 1), a significant reduction of iron occurred for all four geomaterials exposed to the most acidic solution, especially for the BRS, likely due to the acidic attack to the iron oxides adsorbed on the surface of soil particles, evidenced by the loss of hematite $\left(\mathrm{Fe}_{2} \mathrm{O}_{3}\right)$ and

Table 3 - Mineral composition of geomaterials samples.

\begin{tabular}{|c|c|c|}
\hline OFS Pure & OFS $0.00 \mathrm{~mol} / \mathrm{L}$ & OFS $1.00 \mathrm{~mol} / \mathrm{L}$ \\
\hline Quartz & Quartz & Quartz \\
\hline Microcline & Microcline & Microcline \\
\hline Albite & Albite & Gibbsite \\
\hline BRS Pure & BRS $0.00 \mathrm{~mol} / \mathrm{L}$ & BRS $1.00 \mathrm{~mol} / \mathrm{L}$ \\
\hline Quartz & Quartz & Quartz \\
\hline Hematite & Hematite & Alunogen \\
\hline Kaolinite & Kaolinite & Coquimbita \\
\hline Anatase & Anatase & Kaolinite \\
\hline - & - & Pyrophyllite \\
\hline- & - & Microcline \\
\hline KAO Pure & $\mathrm{KAO} 0.00 \mathrm{~mol} / \mathrm{L}$ & KAO $1.00 \mathrm{~mol} / \mathrm{L}$ \\
\hline Quartz & Quartz & Quartz \\
\hline Kaolinite & Kaolinite & Kaolinite \\
\hline Microcline & Microcline & Microcline \\
\hline Muscovite & Muscovite & Muscovite \\
\hline- & - & Alunogen \\
\hline BEN Pure & $\mathrm{BEN} 0.00 \mathrm{~mol} / \mathrm{L}$ & $\mathrm{BEN} 1.00 \mathrm{~mol} / \mathrm{L}$ \\
\hline Quartz & Quartz & Quartz \\
\hline Kaolinite & Kaolinite & Kaolinite \\
\hline Microcline & Microcline & Microcline \\
\hline Muscovite & Muscovite & Muscovite \\
\hline Calcite & Calcite & Alunogen \\
\hline Hydrobiotite & Hydrobiotite & - \\
\hline
\end{tabular}

the formation of coquimbite $\left(\mathrm{Fe}_{2}\left(\mathrm{SO}_{4}\right)_{3} 9 \mathrm{H}_{2} \mathrm{O}\right)$ and pyrophyllite $\left(\mathrm{Al}_{2} \mathrm{Si}_{4}(\mathrm{OH})\right.$ in the sample exposed to the $1.00 \mathrm{~mol} / \mathrm{L}$ solution. For the other geomaterials exposed to the most acidic solution, there was also a significant reduction in the $\mathrm{Al}$ content, as well as in the other constituent elements (Table 2), which was corroborated by the loss of albite $\left(\mathrm{Na}\left(\mathrm{AlSi}_{3} \mathrm{O}_{8}\right)\right)$ and the formation of gibbsite $\left(\mathrm{Al}(\mathrm{OH})_{3}\right)$ in the OFS; the loss of anatase $\left(\mathrm{TiO}_{2}\right)$ in the BRS; the loss of calcite $\left(\mathrm{CaCO}_{3}\right)$ and hydrobiotite $\left(\mathrm{KMgAlSiO}_{2} \mathrm{H}_{2} \mathrm{O}\right)$ in the $\mathrm{BEN}$; and the formation of alunogen $\left(\mathrm{Al}_{2}\left(\mathrm{SO}_{4}\right)_{3} 17 \mathrm{H}_{2} \mathrm{O}\right)$ in the BRS, $\mathrm{KAO}$, and BEN. The hydrate sulfate alunogen present in the samples is explained by the increased sulfur content. Similarly, there was a correspondence between anatase loss in the SRB and calcite loss in the BEN, with a significant reduction in $\mathrm{Ti}$ and $\mathrm{Ca}$ contents for both geomaterials (Table 2).

The OFS showed lesser chemical reactivity in contact with sulfuric acid compared to the other geomaterials, which is plausible since this soil is mostly composed of quartz. From the works of MacCarthy et al. (2014) and Brady \& Walther (1989), it may be inferred that the acid concentrations, $\mathrm{pH}$ values and temperature conditions used in the present study promoted the dissolution of amorphous silica and that the presence of $\mathrm{Fe}, \mathrm{Al}, \mathrm{Mg}, \mathrm{Si}$, and $\mathrm{Na}$ influenced the adsorption rate or the attack of $\mathrm{H}^{+}$ions to the active sites of quartz particles.

In general, the exposure of the geomaterials to the $1.00 \mathrm{~mol} / \mathrm{L}$ solution resulted in liquid extracts with higher metal concentrations. These results correspond to the elementary and mineralogical variations of the geomaterials. In this regard, it is important to note that in acidic environments, mineral structure dissolution, cation leaching, anion adsorption, changes in the clay particles edge charges and the diffuse double layer, and the formation of sulfate minerals are able to affect the engineering behavior of soils (Bakhshipour et al., 2016; Chavali et al., 2018). In the present study, the expressive concentration of several metals found in the liquid extracts, especially for the BEN exposed to the $1.00 \mathrm{~mol} / \mathrm{L}$ solution, correspond to liquids with higher concentrations of multivalent cations. These cations (such as $\mathrm{Ca}^{+2}$ and $\mathrm{Mg}^{+2}$ ) tend to shrink the diffuse double layer in clay particles, causing soil flocculation, macropore formation and consequently increased hydraulic conductivity (Amadi, 2011; Mitchell, 1993; Ruhl \& Daniel, 1997).

Spagnoli et al. (2012) report that kaolinite has no forces in the double layer because the surface charge is considered neutral. According to Bakhshipour et al. (2016), in residual soils consisting mainly of illite, kaolinite, and goethite, acidic contamination does not provoke changes in the diffuse double layer sufficient to promote variations in properties such as Atterberg limits, hydraulic conductivity, and compaction characteristics. In contrast, in smectite clay minerals, both faces have oxide $\left(\mathrm{O}^{2-}\right)$ terminations, and the edges have hydroxide $(\mathrm{OH})$ and $\mathrm{O}^{2-}$ terminations. In smectites, the diffuse double layer governs the mechanical prop- 
erties, since oscillations in the $\mathrm{pH}$ increase the concentration of ions in the double layer. At low $\mathrm{pH}$ values, the increase in $\mathrm{H}^{+}$concentration causes the reduction of the double layer (Spagnoli et al., 2012).

The available literature suggests that the effects of inorganic acids on different types of geomaterial might include dissolution of minerals, leaching of metals such as iron and aluminum, and high loss of cations, which in turn influence properties such as Atterberg limits, expandability, maximum dry density, optimal moisture content, mechanical strength, and permeability.

\section{Conclusions}

In this study, the physical-chemical composition of the liquid extracts and the elemental compositions of four geomaterials exposed to sulfuric acid solutions were evaluated and related to changes in their mineralogical constitution. The following experimental findings were achieved:

- The $\mathrm{pH}$ values showed that only the bentonite liquid extract reached a pH above neutrality after exposure to the $0.01 \mathrm{~mol} / \mathrm{L} \mathrm{H}_{2} \mathrm{SO}_{4}$ solution. Under higher acid concentration, the liquid extracts remained at $\mathrm{pH}$ did not present a buffer capacity for that level of acid concentration with values close to the initial value $(\mathrm{pH} \sim 0)$;

- The electrical conductivity results showed a positive correlation with the increase of acid concentration, indicating a higher concentration of dissolved ions in the liquid extracts of geomaterials submitted to the $1.00 \mathrm{~mol} / \mathrm{L}$ $\mathrm{H}_{2} \mathrm{SO}_{4}$ solution;

- Exposure to the $1.00 \mathrm{~mol} / \mathrm{L}$ solution of $\mathrm{H}_{2} \mathrm{SO}_{4}$ resulted in the solubilization of metals, mainly in basalt residual soil and bentonite. The concentrations of metals in the liquid extracts matched the reduction of the geomaterial constituent elements, as well as the alterations in the mineralogical composition, with loss and formation of minerals.

In conclusion, when considering the potential application of the geomaterials studied to constitute impermeable barriers, one should pay attention to the solubilization of metals and loss of minerals in extreme acidity conditions and the associated susceptibility to structural changes and consequent modification in the mechanical properties and hydraulic performance of waterproofing systems.

\section{Acknowledgments}

This study was financed in part by the Coordenação de Aperfeiçoamento de Pessoal de Nível Superior (CAPES), Brazil - Finance Code 001. The authors are also grateful for the financial support of Fundação de Amparo à Pesquisa do Estado do Rio Grande do Sul (FAPERGS) (Grant 16/2551-0000205-3, Note 08/2014 - First Project Programs) and CNPq (Grants 486506/2013-4, 312756/2017-8, 438328/2018-3).

\section{References}

ABNT (2016). Amostras de Solo: Preparação para Ensaios de Compactação e Caracterização - NBR 6457. ABNT, Rio de Janeiro, Brazil, 12 p.

ABNT (1995). Rochas e Solos - NBR 6502. ABNT, Rio de Janeiro, Brazil, 18 p.

Agbenyeku, E.E.; Muzenda, E. \& Msibi, M.I. (2016). Chemical alterations in three clayey soils from percolation and interaction with acid mine drainage (AMD). South African Journal of Chemical Engineering, 21:28-36. https://doi.org/10.1016/j.sajce.2016.04.003.

Amadi, A.A. (2011). Hydraulic conductivity tests for evaluating compatibility of lateritic soil-fly ash mixtures with municipal waste leachate. Geotechnical and Geological Engineering, 29(3):259-265. https://doi.org/10.1007/s10706-010-9358-9.

Asof, M.; Rachman, S.A.; Nurmawi, W.A. \& Ramayanti, C. (2017). Recovery of $\mathrm{H}_{2} \mathrm{SO}_{4}$ from spent acid waste using bentonite adsorbent. Proc. MATEC Web of Conferences, v. 101, pp. 02007. https://doi.org/ 10.1051/matecconf/201710102007

ASTM (1993). Standard Practice for Classification of Soils for Engineering Purposes (Unified Soil Classification System) - D2487-06. ASTM International, West Conshohocken, Pennsylvania, USA, 12 p.

ASTM (2008). Standard Test Method for 24-h Batch-Type Measurement of Contaminant Sorption by Soils and Sediments - D4646-03. ASTM International, West Conshohocken, Pennsylvania, USA, 4 p.

Bakhshipour, Z.; Asadi, A.; Huat, B.B.K.; Sridharan, A. \& Kawasaki, S. (2016). Effect of acid rain on geotechnical properties of residual soils. Soils and Foundations, 56(6):1008-1020.

https://doi.org/10.1016/j.sandf.2016.11.006.

Blowes, D.W.; Ptacek, C.J.; Jambor, J.L.; Weisener, C.G.; Paktunc, D.; Gould, W.D. \& Johnson, D.B. (2014) The geochemestry of acid mine drainage. D.W. Blowes, C.J. Ptacek, J.L. Jambor, and C.G. Weisener (eds), Treatise on Geochemestry, Elsevier, Oxford, pp. 131-190. https://doi.org/10.1016/B978-0-08-095975-7.00905-0.

Bouazza, A.; Vangpaisal, T. \& Jefferis, S. (2006). Effect of wet-dry cycles and cation exchange on gas permeability of geosynthetic clay liners. Journal of Geotechnical and Geoenvironmental Engineering, 132(8):1011-1018. https://doi.org/10.1061/(ASCE)1090-0241(2006)132:8 (1011).

Brady, P.V. \& Walther, J.V. (1989). Controls on silicate dissolution rates in neutral and basic $\mathrm{pH}$ solutions at $25{ }^{\circ} \mathrm{C}$. Geochimica et Cosmochimica Acta, 53(11):2823-2830. https://doi.org/10.1016/0016-7037(89)90160-9.

Caglar, B.; Afsin, B.; Koksal, E.; Tabak, A. \& Eren, E. (2013). Characterization of unye bentonite after treat- 
ment with sulfuric acid. Quimica Nova, 36(7):955-959. https://doi.org/10.1590/S0100-40422013000700006.

Candeias, C.; Freire, P.; Ferreira, E.; Ferreira, A.; Rita, A. $\&$ Paulo, J. (2014). Acid mine drainage from the Panasqueira mine and its influence on Zêzere river (Central Portugal). Journal of African Earth Sciences, 99:705712. https://doi.org/10.1016/j.jafrearsci.2013.10.006.

Chavali, R.V.P.; Reddy, P.H.P.; Murthy, R.V. \& Sivapullaiah, P.V. (2018). Swelling characteristics of soils subjected to acid contamination. Soils and Foundations, 58(1):110-121.

https://doi.org/10.1016/j.sandf.2017.11.005.

Chavali, R.V.P.; Vindula, S.K.; Reddy, P.H.P.; Babu, A. \& Pillai, R.J. (2017). Swelling behavior of kaolinitic clays contaminated with alkali solutions: A micro-level study. Applied Clay Science, 135:575-582. https://doi.org/10.1016/j.clay.2016.10.045.

Egloffstein, T.A. (2001). Natural bentonites - Influence of the ion exchange and partial desiccation on permeability and self-healing capacity of bentonites used in GCLs. Geotextiles and Geomembranes, 19(7):427-444. https://doi.org/10.1016/S0266-1144(01)00017-6.

Ghadr, S. \& Assadi-Langroudi, A. (2018). Structure-based hydro-mechanical properties of sand-bentonite composites. Engineering Geology, 235:53-63. https://doi.org/10.1016/j.enggeo.2018.02.002.

González-Fernández, B.; Rodríguez-Valdés, E.; Boente, C.; Menéndez-Casares, E.; Fernández-Braña, A. \& Gallego, J.R. (2018). Long-term ongoing impact of arsenic contamination on the environmental compartments of a former mining-metallurgy area. Science of the Total Environment, 610-611:820-830. https://doi.org/10.1016/j.scitotenv.2017.08.135.

Grande, J.A.; Santisteban, M.; de la Torre, M.L.; Dávila, J.M. \& Pérez-Ostalé, E. (2018). Map of impact by acid mine drainage in the river network of The Iberian Pyrite Belt (Sw Spain). Chemosphere, 199:269-277. https://doi.org/ 10.1016/j.chemosphere.2018.02.047.

Gueddouda, M.K.; Goual, I.; Benabed, B.; Taibi, S. \& Aboubekr, N. (2016). Hydraulic properties of dune sand-bentonite mixtures of insulation barriers for hazardous waste facilities. Journal of Rock Mechanics and Geotechnical Engineering, 8(4):541-550. https://doi.org/10.1016/j.jrmge.2016.02.003.

Hamdi, N. \& Srasra, E. (2013). Hydraulic conductivity study of compacted clay soils used as landfill liners for an acidic waste. Waste Management, 33(1):60-66. https://doi.org/10.1016/j.wasman.2012.08.012.

Hassanlourad, M.; Khatami, M.H. \& Ahmadi, M.M. (2016). Effects of sulphuric acid pollutant on the shear behaviour and strength of sandy soil and sand mixed with bentonite clay. International Journal of Geotechnical Engineering, 11(2):114-119. https://doi.org/10.1080/19386362.2016.1193662.
Hueckel, T.; Kaczmarek, M. \& Caramuscio, P. (1997). Theoretical assessment of fabric and permeability changes in clays affected by organic contaminants. Canadian Geotechnical Journal, 34(4):588-603. https://doi.org/ 10.1139/t97-013.

Knop, A.; VanGulck, J.; Heineck, K.S. \& Consoli, N.C. (2008). Compacted artificially cemented soil-acid leachate contaminant interactions: Breakthrough curves and transport parameters. Journal of Hazardous Materials, 155(1-2):269-276. https://doi.org/10.1016/j.jhazmat.2007.11.056.

Koch, D. (2002). Bentonites as a basic material for technical base liners and site encapsulation cut-off walls. Applied Clay Science, 21:1-11. https://doi.org/10.1016/S0169-1317(01)00087-4.

Korf, E.P.; Prietto, P.D.M.; Silveira, A.A.; Ulsen, C.; Consoli, N.C. \& Bragagnolo, L. (2020). Modifications in the chemical and minerealogical composition of compacted mature residual soil submitted to the percolation of acidic leachates. Soils and Rocks, 43(1):159-167. https://doi.org/ 10.28927/SR.43100X.

Leite, G.L.D.; Veloso, R.V.S.; Zanuncio, J.C.; Fernandes, L.A. \& Almeida, C.I.M. (2006). Phenology of Caryocar brasiliense in the Brazil cerrado region. Forest Ecology and Management, 236 (2-3):286-294. https://doi.org/10.1016/j.foreco.2006.09.013.

Leite, M.V.M.; Bobul'ská, L.; Espíndola, S.P.; Campos, M.R.C.; Azevedo, L.C.B. \& Ferreira, A.S. (2018). Modeling of soil phosphatase acitvity in land use ecosystems and topsoil layers in the Brazilian Cerrado. Ecological, $\quad 385: 182-188$. https://doi.org/10.1016/j.ecolmodel.2018.07.022.

Li, J.; Xue, Q.; Wang, P. \& Liu, L. (2013). Influence of leachate pollution on mechanical properties of compacted clay: A case study on behaviors and mechanisms. Engineering Geology, 167:128-133. https://doi.org/10.1016/j.enggeo.2013.10.013.

Liu, Y.; Bouazza, A.; Gates, W.P. \& Rowe, R.K. (2015). Hydraulic performance of geosynthetic clay liners to sulfuric acid solutions. Geotextiles and Geomembranes, 43(1):14-23. https://doi.org/10.1016/j.geotexmem.2014.11.004.

Liu, Y.; Gates, W.P. \& Bouazza, A. (2013). Acid induced degradation of the bentonite component used in geosynthetic clay liners. Geotextiles and Geomembranes, 36:71-80.

Luo, C.; Routh, J.; Dario, M.; Sarkar, S.; Wei, L.; Luo, D. \& Liu, Y. (2020). Distribution and mobilization of heavy metals at an acid mine drainage affected region in South China, a post-remediation study. Science of the Total Environment, 724:138122. https://doi.org/10.1016/j.geotexmem.2012.10.011.

MacCarthy, J.; Nosrati, A.; Skinner, W. \& Addai-Mensah, J. (2014). Dissolution and rheological behaviour of hematite and quartz particles in aqueous media at $\mathrm{pH} 1$. 
Chemical Engineering Research and Design, 92(11):2509-2522. https://doi.org/10.1016/j.cherd.2014.02.020.

Mao, X.; Xiong, L.; Hu, X.; Yan, Z.; Wang, L. \& Xu, G. (2018). Remediation of ammonia-contaminated groundwater in landfill sites with electrochemical reactive barriers: A bench scale study. Waste Management, 78:69-78. https://doi.org/10.1016/j.wasman.2018.05.015.

Mazzieri, F.; Di Emidio, G. \& Pasqualini, E. (2017). Effect of wet-and-dry ageing in seawater on the swelling properties and hydraulic conductivity of two amended bentonites. Applied Clay Science, 142:40-51. https://doi.org/10.1016/j.clay.2016.10.031

Miguel, M.G.; Barreto, R.P. \& Pereira, S.Y. (2017). Study of a tropical soil in order to use it to retain aluminum, iron, manganese and fluoride from acid mine drainage. Journal of Environmental Management, 204:563-570. https://doi.org/10.1016/j.jenvman.2017.09.024.

Mitchell, J.K. (1993). Fundamentals of soil behavior, 2nd ed. John Wiley \& Sons, New York, 456 p.

Morandini, T.L.C. \& Leite, A.L. (2015). Characterization and hydraulic conductivity of tropical soils and bentonite mixtures for CCL purposes. Engineering Geology, 196:251-267.

https://doi.org/10.1016/j.enggeo.2015.07.011

Nessa, S.A.; Idemitsu, K.; Yamasaki, Y.; Inagaki, Y. \& Arima, T. (2007). Measurement of pH of the compacted bentonite under the reducing condition. Memoirs of the Faculty of Engineering, 67(1):25-31.

Pecorini, I.; Baldi, F.; Bacchi, D.; Carnevale, E.A. \& Corti, A. (2017). Leaching behaviour of hazardous waste under the impact of different ambient conditions. Waste Management, 63:96-106. https://doi.org/10.1016/j.wasman.2016.10.037.

Ruhl, J.L. \& Daniel, D.E. (1997). Geosynthetic clay liners permeated with chemical solutions and leachates. Journal of Geotechnical and Geoenvironmental Engineering, 123(4):369-381. https://doi.org/10.1061/(ASCE)1090-0241(1997)123:4 (369).
Shackelford, C.D.; Benson, C.H.; Katsumi, T.; Edil, T.B. \& Lin, L. (2000). Evaluating the hydraulic conductivity of GCLs permeated with non-standard liquids. Geotextiles and Geomembranes, 18(2-4):133-161. https://doi.org/10.1016/S0266-1144(99)00024-2.

Spagnoli, G.; Rubinos, D.; Stanjek, H.; Fernández-Steeger, T.; Feinendegen, M. \& Azzam, R. (2012). Undrained shear strength of clays as modified by $\mathrm{pH}$ variations. Bulletin of Engineering Geology and the Environment, 71:135-148. https://doi.org/10.1007/s10064-011-0372-9.

Streck, E.V.; Kampf, N.; Dalmolin, R.S.D.; Klamt, E.; Nascimento, P.C.; Giasson, E. \& Pinto, L.F.S. (2008). Solos do Rio Grande do Sul, 2 ed. EMATER/RSASCAR, Porto Alegre, 222 p. https://doi.org/10.1016/S0016-7061(02)00225-2.

Sucha, V.; Dubiková, M.; Cambier, P.; Elsass, F. \& Pernes, M. (2002). Effect of acid mine drainage on the mineralogy of a dystric cambisol. Geoderma, 110(3-4):151167. https://doi.org/10.1016/S0016-7061(02)00225-2.

Sunil, B.M.; Nayak, S. \& Surathkal, S. (2006). Effect of pH on the geotechnical properties of laterite. Engineering Geology, 85(1):197-203. https://doi.org/10.1016/j.enggeo.2005.09.039.

USEPA (1996). Acid digestion of sediments, sludges, and soils - Method 3050B. USEPA, Washington, USA, $12 \mathrm{p}$.

Verástegui-Flores, R.D. \& Di Emidio, G. (2014). Impact of sulfate attack on mechanical properties and hydraulic conductivity of a cement-admixed clay. Applied Clay Science, 101:490-496. https://doi.org/10.1016/j.clay.2014.09.012.

Wang, S.; Zhu, W.; Fei, K.; Xu, C. \& Zhang, N. (2018). Study on non-darcian flow sand-clay mixtures. Applied Clay Science, 151:102-108. https://doi.org/10.1016/j.clay.2017.10.028.

Wang, Y.; Chen, Y.; Xie, H.; Zhang, C. \& Zhan, L. (2016). Lead adsorption and transport in loess-amended soilbentonite. Engineering Geology, 215:69-80. https://doi.org/10.1016/j.enggeo.2016.11.002.

Yong, R.N.; Warkentin, B.P.; Phadungchewit, Y. \& Galvez, R. (1990). Buffer capacity and lead retention in some clay materials. Water, Air, and Soil Pollution, 53:53-67. https://doi.org/10.1007/BF00154991. 